\title{
28 Research Square \\ Effect of Bleomycin on Oral Leukoplakia Cell line- an in Vitro Study
}

\section{Al Moutassem B. Khair}

Ajman University

Alexander Luke ( $\square$ a.luke@ajman.ac.ae )

Ajman University

Shishir R. Shetty

Ajman University

Simy Mathew

Ajman University

Rajashree Patnaik

Ajman University

\section{Research article}

Keywords: Leukoplakia, Bleomycin, Squamous cell carcinoma, AO/EB staining, PI staining, MTT assay, Probit computation

Posted Date: September 21st, 2020

DOI: https://doi.org/10.21203/rs.3.rs-66903/v1

License: (c) (i) This work is licensed under a Creative Commons Attribution 4.0 International License.

Read Full License 


\section{Abstract}

Background Leukoplakia generally refers to a firmly attached white patch on a mucous membrane which is associated with an increased risk of cancer. So it is important to diagnose leukoplakia in early stage. In this study we are trying to treat leukoplakia as a marker for prediagnosis of cancer. Since, bleomycin as a chemotherapeutic agent, is mainly used in the treatment of multiple tumors, and several cancers. Hence in this study effect of bleomycin was studied in D38, a leukoplakia cell line.

Methods Percent lethality values of leukoplakia cells after treated with several concentations of bleomycin was studied by acridine orange/ethidium bromide staining (AO/EB), propidium iodide (PI) staining, 3-(4, 5-dimethythiazol-2-yl)-2, 5-diphenyl tetrazolium bromide (MTT) assay and comet assay. Minimum inhibitory concentration (MIC), lethal concentration ${ }_{25}\left(\mathrm{LC}_{25}\right)$, lethal concentration ${ }_{50}\left(\mathrm{LC}_{50}\right)$, lethal concentration ${ }_{75}\left(\mathrm{LC}_{75}\right)$ and highest permissive concentration (HPC) was calculated from probit computational method.

Results From AO/EB staining, PI staining, MTT assay and comet assay the MIC value was $15 \mathrm{mg} / \mathrm{L}$ concentration of bleomycin, where as the HPC was found at $100 \mathrm{mg} / \mathrm{L}$ of bleomycin. The comet tail length gradually increased from $15 \mathrm{mg} / \mathrm{L}$ to $100 \mathrm{mg} / \mathrm{L}$ of bleomycin. Percent lethality values were also increased from 15 to $100 \mathrm{mg} / \mathrm{L}$ concentration of bleomycin in all the staining protocols as well as in comet assay technique.

Conclusion It is important to diagnose leukoplakia in early stage. Since, bleomycin as a chemotherapeutic agent, it is mainly used in the treatment of multiple tumors, testicular carcinomas, lymphomas, and head, neck cancers. From the results, it was found that bleomycin can be used for treatment of oral leukoplakia to prevent its development to SCC.

\section{Background}

Over the years potentially malignant disorders like oral leukoplakia (OL) and oral erythroplakia (OE) are associated with dysplastic cellular changes and hence carry a risk of undergoing malignant transformation leading to oral cancer (OC) [1]. Numerous surgical and nonsurgical modalities have been used for treatment of OL [2]. Some of the non-surgical modalities used for the treatment of OL include photodynamic therapy, beta-carotene, lycopene, or vitamin A $[2,3]$. Bleomycin a chemotherapeutic agent has also been used for treatment of leukoplakia and other malignant lesions $[4,5,6,7,8]$. Apart from topical application report intralesional injection of bleomycin into OL lesion has been performed with good results [9]. Another study suggested the delivery of bleomycin into head and neck tumors using iontophoresis [10]. Bleomycin is isolated from the bacteria Streptomyces verticillis [11, 12, 13], which is a glycopeptide antibiotic. As a chemotherapeutic agent, it is mainly used in the treatment of multiple tumors, testicular carcinomas, lymphomas, and head, neck cancers [14, 15]. The biological action of bleomycin is through a sequence-selective, metal-dependent oxidative cleavage of DNA and RNA in the presence of oxygen. It can mediate the oxidative degradation of all major classes of cellular RNAs and 
inhibition of DNA synthesis $[13,16]$. Still its mechanism of action has not been elucidated. It has been reported that Bleomycin is responsible for lipid peroxidation and mitochondrial DNA damage [17]. Bleomycin induces G2/M cell cycle arrest, which is important for genomic stability, in cancer cell lines. It causes senescence, apoptosis and mitotic cell death $[18,19,20]$.

Studies have suggested intralesional injection of bleomycin to be highly effective in treatment of warts [21]. Off-label use of intralesional bleomycin is another primary and/or adjunctive therapy for different cutaneous lesions dermatology as several types of cutaneous malignancies, telangiectasias, vascular malformations, hemangiomas, and lesions of leishmaniasis cutisand condyloma acuminate [22]. Studies have also suggested intralesional bleomycin to be more effective in treatment of warts when compared to surgical modalities like cryotherapy [23]. Recent research has revealed that bleomycin is a reliable and safe treatment modality for warts resistant to other therapeutics [24].

Bleomycin along with Adriamycin, vinblastine and dacarbazine is the standard chemotherapy regimen for Hodgkin's, and non-Hodgkin's lymphoma disease squamous cell cancers, sarcoma, melanoma, and testicular cancer. Also it is used to treat malignant pleural effusion and Leukemias [25]. Bleomycin is found to concentrate more in lymphoid tissue and does not cause excessive myelo-suppression, thus is the preferred agent in chemotherapeutic regimens for non hodgkins lymphoma also [26]. Bleomycin is one of the important drugs in induction chemotherapy for testicular cancer [27]. Bleomycin also is a key component in the chemotherapy regimens for cervical and ovarian cancer $[28,29]$.

In this study, effect of bleomycin was studied by using D38 cell line which is a leukoplakia cell line. Percent lethal values after the leukoplakia cells treated with several concentration of bleomycin, were calculated from probit table. $\mathrm{LC}_{25}, \mathrm{LC}_{50}$, and $\mathrm{LC}_{75}$ values were calculated by taking the $\log _{10}$ concentrations of obtained percent lethality. MIC and HPC values were calculated directly from the experiment.

\section{Methods}

\section{Cell Culture}

Human leukoplakia cell line D38, were used for this study. The cell line was purchased from NCCS, Pune, India. After getting the cell line, cells were washed thoroughly with PBS and the cell number was counted. The cells were cultured in Dulbecco's modified eagle media (DMEM) containing 10\% FBS (Fetal Bovine Serum) and $1 \%$ penicillin-streptomycin solution in six well culture plate. The cells were kept in an incubator at $5 \% \mathrm{CO}_{2}$ and at $37^{\circ} \mathrm{C}$ temperature. The cells were maintained by changing the media in two days interval. After getting confluent cells were transferred to 96 -well culture plates at concentration of $1 \times 10^{4}$ cells/well for study of effect of bleomycin. The cells were treated with several concentrations of bleomycin $(0,15,25,50,75,90$ and $100 \mathrm{mg} / \mathrm{L})$ and were incubated for 24 hours. After the incubation period, viability of cells were studied by acridine orange/ethidium bromide staining (AO/EB), propidium 
iodide (PI) staining, 3-(4, 5-dimethythiazol-2-yl)-2, 5-diphenyl tetrazolium bromide (MTT) assay and comet assay.

\section{AO/EB staining}

The AO/EB solution was prepared in PBS at the concentration of $100 \mu \mathrm{g} / \mathrm{mL}$ and is applied to in vitro cultured cells. When observed under the fluorescent microscope at 400X, green colour indicated live cells, whereas cells with orange and red colour were recorded as apoptotic and necrotic cells, respectively. AO is taken up by both live and dead cells and emits green fluorescence whereas EB is only taken up by dead cells, as the integrity cytoplasmic membrane is lost and it stains nucleus orange. Hence live cells, apoptotic cells and necrotic cells were green, orange and red in appearance, respectively.

\section{PI staining}

The working solution for PI staining was prepared after mixing PI stock solution ( $1 \mathrm{mg} / \mathrm{mL}$ ) with PBS in the ratio 1:9. For monitoring the viability, an aliquot of $20 \mu \mathrm{L}$ of cell suspension grown in the presence of bleomycin was mixed properly with an aliquot of $20 \mu \mathrm{L}$ of the working PI solution. The viable cells would appear green and the nucleus of non-viable cells would appear red in colour, under the fluorescent microscope. Toxicity values were obtained after a $24 \mathrm{~h}$ of incubation. Probits of observed lethality percentage values were used for analysis of toxicity. The dye, PI binds to DNA by entering dead cells only, which appear red in colour whereas the live cells appear green in fluorescent light.

\section{MTT assay}

The MTT solution was prepared at the concentration of $5 \mathrm{mg} / \mathrm{mL}$ in PBS. After $24 \mathrm{~h}$ of bleomycin treatment in a 6-well culture plate, $80 \mu \mathrm{L}$ of MTT solution was added to each well to study the toxicity effect. The plate was kept in an incubator $\left(37^{\circ} \mathrm{C}, 5 \% \mathrm{CO}_{2}\right)$ for $4 \mathrm{~h}$. Then, it was found that the media containing the cells and chemicals converted to blue colour after incubated with MTT. Then gently the mass was centrifuged at $1000 \mathrm{rpm}$ for $10 \mathrm{~min}$ at $22^{\circ} \mathrm{C}$. The supernatant was removed and the pellet was dissolved in an aliquot of $1 \mathrm{~mL} 100 \%$ dimethyl sulfoxide (DMSO) and kept in the incubator $\left(37^{\circ} \mathrm{C}, 5 \%\right.$ $\mathrm{CO}_{2}$ ) for $1 \mathrm{~h}$. The mixture turned purple and its optical density (OD) was measured with a spectrophotometer at the $570 \mathrm{~nm}$ wavelength.

Percentage of cell density $=100 \times\left(\mathrm{OD}_{\text {sample }}-\mathrm{OD}_{\text {blank }}\right) / \mathrm{OD}_{\text {control}} ; \mathrm{MTT}$ in DMSO solution was taken as the blank. Probits of observed lethality percentage values were used for analysis of toxicity.

\section{Comet assay}


Single cell gel electrophoresis was carried out to study DNA damage of the treated cell lines. Cultured cells were harvested and used in the alkaline comet assay technique. After coating slides with $1 \%$ agarose, the slides were allowed for air dried. Treated cells with different concentrations of bleomycin were centrifuged and pellets were washed with PBS; and the washed cells were mixed with three times the cell volume with the low melting point agarose (LMPA) $1 \%$ in sol state. The mixture of cells and LMPA sol was placed over the agarose coated slide that was dried at $4^{\circ} \mathrm{C}$ for $10 \mathrm{~min}$. The slides were further treated with $1 \%$ Triton X 100,10\% DMSO, individually, and were placed in the lysing solution of the mixture of $100 \mathrm{mM} \mathrm{Na}_{2} \mathrm{EDTA}, 10 \mathrm{mM}$ Tris, $2.5 \mathrm{mM} \mathrm{NaCl}(\mathrm{pH}, 10)$, at $4^{\circ} \mathrm{C}$ for $1 \mathrm{~h}$. The slides were subsequently removed and placed in the electrophoretic buffer consisting of $1 \mathrm{mM} \mathrm{Na}_{2}$ EDTA and 300 $\mathrm{mM} \mathrm{NaOH}(\mathrm{pH}, 13)$ for $30 \mathrm{~min}$. The slides were subjected to electrophoresis was carried out at $1.0 \mathrm{~V} / \mathrm{cm}$ for $30 \mathrm{~min}$, and the slides were placed in the neutralizing solution $(0.4 \mathrm{M}$ Tris $\mathrm{HCl}, \mathrm{pH}, 7.5)$ for $5 \mathrm{~min}$ (Tice et al. 2000). The slides were stained with an aliquot of $40 \mu \mathrm{L}$ of $10 \mu \mathrm{g} / \mathrm{mL}$ EB solution. Comets were scored with a fluorescence microscope at 400X and the DNA fragmentation index (DFI) as percent values were presented. Hydrogen peroxide $100 \mu \mathrm{M}$ solution was used as the positive control. Values of comet tail length were measured with the help of an ocular micrometer.

\section{Results}

\section{AO/EB staining}

The number of dead cells gradually increased from the level of 15 to $100 \mathrm{mg} / \mathrm{L}$ level, assessed from colour variation of cells. Experimentally, the lethality was found seen at $15 \mathrm{mg} / \mathrm{L}$, which was recorded as the MIC. From the plot, it was ascertained that for values of $\mathrm{LC}_{25}, \mathrm{LC}_{50}$, and $\mathrm{LC}_{75}$ with probit values, $4.3255,5.0000$ and 5.6745 , respectively, corresponding $\log _{10}$ concentration values were $1.53,1.68$ and 1.82 , respectively. Antilog values of these $\log _{10}$ concentration values are $33.88\left(\mathrm{LC}_{25}\right), 47.86\left(\mathrm{LC}_{50}\right)$ and $66.07\left(\mathrm{LC}_{75}\right)$, which in $\mathrm{mg} / \mathrm{L}$ are the computed $\mathrm{LC}$ values of bleomycin; the individual MIC and HPC values were noted directly from experiments.

\section{PI staining}

From PI staining results, the minimum live cell density was determined as $65.8 \%$ at $15 \mathrm{mg} / \mathrm{L}$ bleomycin, i.e., it was the MIC value. The HPC was $100 \mathrm{mg} / \mathrm{L}$ bleomycin. The probit plot yielded $\log _{10}$ concentrations as, $1.59,1.72$ and 1.85 , which on extrapolation, yielded computed lethal values, $38.99\left(\mathrm{LC}_{25}\right), 52.06\left(\mathrm{LC}_{50}\right)$ and $70.96 \mathrm{mg} / \mathrm{L}\left(\mathrm{LC}_{75}\right)$, respectively, by the probit computation.

\section{MTT assay}

From the cell density as $\mathrm{OD}_{570}$ and cell viability the level of $100 \mathrm{mg} / \mathrm{L}$ was recorded as the HPC. Experimentally, the MIC value was $15 \mathrm{mg} / \mathrm{L}$ bleomycin. Probits of percentage lethality (PL) and 
corresponding $\log _{10}$ values of bleomycin concentrations were used for the plot that yielded $\log _{10}$ levels for $L C_{25}, L C_{50}$, and $L C_{75} \log _{10}$, as $1.42,1.70$ and 1.91, respectively; these $\log _{10}$ concentration values generated LC values: $26.36\left(\mathrm{LC}_{25}\right), 50.23\left(\mathrm{LC}_{50}\right)$ and $81.47 \mathrm{mg} / \mathrm{L}\left(\mathrm{LC}_{75}\right)$.

\section{Comet assay}

The length of comet tail increased from $15 \mathrm{mg} / \mathrm{L}$ to $100 \mathrm{mg} / \mathrm{L}$ bleomycin. From probit analysis, it was found that the $L_{25}, L_{50}$ and $L_{75}$ values were $26.36,42.76$ and $61.80 \mathrm{mg} / \mathrm{L}$, respectively.

Microphotographs of observed comets at 0 and $42.76 \mathrm{mg} / \mathrm{L}\left(\mathrm{LC}_{50}\right)$ bleomycin, clearly demonstrated the nuclear damage by bleomycin. The mean DFI values from number of cells yielding comet tails and their length values are presented; the mean comet tail length was $16.41 \pm 0.45$ with $100 \mu \mathrm{M} \mathrm{H}_{2} \mathrm{O}_{2}$.

Table 1

Lethality values during Bleomycin toxicity to D38 cells growing in DMEM, assessed by three methods, AO/EB staining, propidium iodide staining and MTT assay.

\begin{tabular}{|llll|}
\hline $\begin{array}{l}\text { Concentration of } \\
\text { Bleomycin (mg/L) }\end{array}$ & $\begin{array}{l}\text { Lethality of cells by } \\
\text { AO/EB staining (\%) }\end{array}$ & $\begin{array}{l}\text { Lethality of cells by } \\
\text { PI staining (\%) }\end{array}$ & $\begin{array}{l}\text { Lethality of cells by } \\
\text { MTT assay (\%) }\end{array}$ \\
\hline 0 & 0 & 0 & 0 \\
\hline 15 & $32.8 \pm 1.20$ & $34.2 \pm 0.79$ & $5.9 \pm 0.43$ \\
\hline 25 & $32.8 \pm 1.31$ & $37.6 \pm 2.09$ & $12.8 \pm 0.45$ \\
\hline 50 & $37.5 \pm 2.28$ & $40.2 \pm 1.91$ & $52.7 \pm 0.81$ \\
\hline 75 & $85.9 \pm 0.87$ & $87.9 \pm 2.32$ & $75.4 \pm 1.32$ \\
\hline 100 & $90.6 \pm 1.57$ & $93.7 \pm 0.72$ & $85.9 \pm 0.70$ \\
\hline $\begin{array}{l}\text { Note: } \text { AO/EB, Acridine orange/ethidium bromide; DMEM, Dulbecco's modified Eagle's medium; MTT, 3- } \\
{[4,5-\text { dimethylthiazol-2-yl] 2,5-diphenyl tetrazolium bromide; Pl, Propidium iodide; -, Not applicable. }}\end{array}$ \\
\hline
\end{tabular}


Table 2

Toxicity values of Bleomycin to D38 cells obtained by experimentation and the probit computation.

\begin{tabular}{|llllll|}
\hline Asssay methods & \multicolumn{5}{c|}{ Toxicity values (mg/L) } \\
\cline { 2 - 6 } & MIC* & $\mathrm{LC}_{25}$ & $\mathrm{LC}_{50}$ & $\mathrm{LC}_{75}$ & HPC* \\
\hline AO/EB staining & 15 & 33.88 & 47.86 & 66.07 & 100 \\
\hline PI staining & 15 & 38.99 & 52.06 & 70.96 & 100 \\
\hline MTT assay & 15 & 26.36 & 50.23 & 81.47 & 100 \\
\hline Comets seen & 15 & 26.36 & 42.76 & 61.80 & 100 \\
\hline *From experiments. LC, lethal concentration. & & \\
\hline
\end{tabular}

Table 3

DNA fragmentation index (DFI) and tail length of comets of D38 cells after growth in the presence of graded concentrations of Bleomycin.

\begin{tabular}{|lll|}
\hline Concentration of Bleomycin $(\mathrm{mg} / \mathrm{L})$ & $\mathrm{DFI}(\%)$ & Tail length $(\mu \mathrm{m})$ \\
\hline 0 & 0 & 0 \\
15 & $4 \pm 2.0$ & $4.26 \pm 0.50$ \\
25 & $19 \pm 1.73$ & $8.16 \pm 0.75$ \\
50 & $62 \pm 2.0$ & $13.3 \pm 0.56$ \\
75 & $84 \pm 5.29$ & $18.5 \pm 1.50$ \\
100 & $93 \pm 3.60$ & $21.2 \pm 0.86$ \\
\hline
\end{tabular}

\section{Discussion}

Since oral leukoplakia has a poor diagnosis, but it may be fatal due to its development to oral squamouscell carcinoma (OSCC). Risk factors for oral carcinoma have been identified, but there are no reliable predictors of the outcome in individual patients with oral leukoplakia. Prevention of leukoplakia to OSCC is important because tramsformation of dysplastic leukoplakiato OSCC is higher in comparison with hyperkeratotic leukoplakia [30]. Chemotherapy may have toxic effects which may be reduced with topical therapy. In a study, it was found that vitamin A has some effect in snuff induced leukoplakia [31, 32]. Daily topical application of bleomycin in DMSO for 15-18 days reduces keratinization and dysplasia [8]. In another study, bleomycin at $0.5 \%$ and $1.0 \%$ has effect in reducing the size and severity of dysplasia after applying once daily for 2 weeks $[1,7]$. 
In this study it was found that bleomycin is effective against leukoplakia cell line D38. After treating bleomycin at several concentrations to D38 cell line, it was observed that the MIC values were $15 \mathrm{mg} / \mathrm{L}$ of bleomycin, whereas the HPC values were $100 \mathrm{mg} / \mathrm{L}$ of bleomycin after 24 hours of incubation, by AO/EB staining, PI staining, MTT assay and comet assay techniques.

Eliminating the use of tobacco and alcohol is the most important aspect of treatment of oral leukoplakia. Now-a-days surgical removal is the common method of management and a choice of treatment by using lasers. But there are some difficult excision sites. In some cases posttreatment complications are also found. So it is difficult to treat the leukoplakia by excision only, in all cases. Hence, bleomycin can be used to prevent the leukoplakia developing to OSCC. Advantages of this approach are easy for application, that doesn't require treatment at a health care centre and relatively low cost as compared to surgical intervention.

\section{Conclusion}

Advances in the management of oral leukoplakia will help in prevention of potential progression of oral leukoplakia to SCC through dysplasia. From this study, it is clear that bleomycin can be used as an active drug for the treatment and management of oral leukoplakia.

\section{Abbreviations}

AO/EB: Acridine orange/ethidium bromide staining; PI: Propidium iodide; MTT: 3-(4, 5-dimethythiazol-2yl)-2, 5-diphenyl tetrazolium bromide; MIC: Minimum inhibitory concentration; LC: Lethal concentration; HPC: Highest permissive concentration; DMEM: Dulbecco's modified eagle media; FBS: Fetal Bovine Serum; LMPA: Low melting point agarose

\section{Declarations}

\section{Acknowledgements}

We are grateful to Dean, College of Dentistry, Ajman University for providing support for this research work.

\section{Authors' Contributions}

Al MB, Khair, AM, Luke conceived and designed the experiment. AM, Luke, SR Shetty, and R Patnaik performed the experiments. S Mathew, SR Shetty interpreted and analysed the data. Al MB, Khair and AM, Luke contributed reagents, materials, analysis tools or data. Al MB, Khair, and R Patnaik wrote the manuscript. 


\section{Funding}

This research was done from the internal grant of Ajman University (Grant Id: 2019-IRG-DEN-3). The grant was used for purchase of chemicals and reagents.

\section{Availability of data and materials}

All data generated and analysed during this study are included in this article. The raw datas during the current study are available from the corresponding author on reasonable requests.

\section{Ethics approval and consent}

This study was approved by institutional ethical committee, Ajman University, Ajman, UAE.

\section{Competing interests}

Authors declare no conflict of interest.

\section{Author details}

${ }^{1}$ Department of Surgical sciences, College of Dentistry, Ajman University, Ajman, UAE. ${ }^{2}$ Department of Surgical sciences, College of Dentistry, Ajman University, Ajman, UAE. ${ }^{3}$ Department of oral Radiology, College of Dental Medicine, Ubiversity of Sharjah. ${ }^{4}$ Department of Surgical sciences, College of Dentistry, Ajman University, Ajman, UAE. ${ }^{5}$ Department of Surgical sciences, College of Dentistry, Ajman University, Ajman, UAE.

\section{References}

1. Epstein JB, Wong FL, Millner A, Le ND. Topical bleomycin treatment of oral leukoplakia: a randomized double-blind clinical trial. Head Neck. 1994;16:539-44. https://doi.org/10.1002/hed.2880160607.

2. Ribeiro AS, Salles PR, da Silva TA, Mesquita RA. A review of the nonsurgical treatment of oral leukoplakia. Int J Dent. 2010. https://doi.org/10.1155/2010/186018.

3. Saito T, Sugiura C, Hirai A, Notani K, Totsuka Y, Shindoh M, et al. Development of squamous cell carcinoma from pre-existent oral leukoplakia: with respect to treatment modality. Int J Oral Maxillofac Surg. 2001;30:49-53. https://doi.org/10.1054/ijom.2000.0012.

4. Lodi G, Sardella A, Bez C, Demarosi F, Carrassi A. Interventions for treating oral leukoplakia. Cochrane Database Syst Rev. 2006;4.CD001829. https://doi.org/10.1002/14651858.CD001829.pub3. 
5. Lele S. Although leukoplakia responds to some treatments relapses and adverse effects are common. Evid Based Dent. 2005;6:15-6. https://doi.org/10.1038/sj.ebd.6400311.

6. de Vries N, van Zandwijk N, Pastorino U. Chemoprevention of head and neck and lung (pre)cancer.Recent Results. Cancer Res. 1999;151:13-25. https://doi.org/10.1007/978-3-642-599453_2.

7. Malmstrom M, Hietanen J, Sane J, Sysmalainen M. Topical treatment of oral leukoplakia with bleomycin. Br J Oral Maxillofac Surg. 1988;26:491-8. https://doi.org/10.1016/0266-4356(88)90071$\mathrm{x}$.

8. Hammersley N, Ferguson MM, Rennie JS. Topical bleomycin in the treatment of oral leukoplakia: a pilot study. Br J Oral Maxillofac Surg. 1985;23:251-8. https://doi.org/10.1016/S02664356(18)30307-3.

9. Hisano Y, Satoh T, Suzuki M, Kanai Y. An effective case of local injection therapy of oral leukoplakia with bleomycin (author's transl). Shigaku. 1978;66:125-8.

10. Hayasaki K, Kitamura T, Kaneko T, Tachibana M, Kobayashi N, Tosaka K, et al. Application of BLMiontophoresis for the tumor-therapy of the head and neck area (author's transl). Nihon Gan Chiryo Gakkai Shi. 1977;12:522-7.

11. Umezawa H. Bleomycin and other antitumor antibiotics of high molecular weight. Antimicrob Agents Chemother (Bethesda). 1965;5:1079-85.

12. Umezawa H, Maeda K, Takeuchi T, Okami Y. New anti-biotics, bleomycin A and B. J Antibiot. 1996;19:200-9.

13. Galm U, Hager MH, Van Lanen SG, Ju J, Thorson JS, Shen B. Antitumor antibiotics: bleomycin, enediynes, and mitomycin. Chem Rev. 2005;105:739-58. https://doi.org/10.1021/cr030117g.

14. Lazo JS. Bleomycin. Cancer Chemother Biol Response Modif. 1999;18:39-45.

15. Chen J, Stubbe J. Bleomycins: towards better therapeutics. Nat Rev Cancer. 2005;5(2):102-12. https://doi.org/10.1038/nrc1547.

16. Yen HC, Chang HM, Majima HJ, Chen FY, Li SH. Levels of reactive oxygen species and primary antioxidant enzymes in WI38 versus transformed WI38 cells following bleomcyin treatment. Free Radic Biol Med. 2005;38:950-59. https://doi.org/10.1016/j.freeradbiomed.2004.12.022.

17. Khaidakov M, Manjanatha MG, Aidoo A. Molecular analysis of mitochondrial DNA mutations from bleomycin-treated rats. Mutat Res. 2002;500:1-8. https://doi.org/10.1016/S0027-5107(01)00270-6.

18. Cloos J, Temmink O, Ceelen M, Snel MH, Leemans CR, et al. Involvement of cell cycle control in bleomycin-induced mutagen sensitivity. Environ Mol Mutagen. 2002;40:79-84. https://doi.org/10.1002/em.10093.

19. Kaneko M, Matsuda D, Ohtawa M. Potentiation of bleomycin in jurkat cells by fungal pycnidione. Biol Pharm Bull. 2012;35:18-28. https://doi.org/10.1248/bpb.35.18.

20. Yen HC, Li SH, Majima HJ. Up-regulation of antioxidant enzymes and coenzyme Q (10) in a human oral cancer cell line with acquired bleomycin resistance. Free Radic Res. 2011;45:707-16. 
https://doi.org/10.3109/10715762.2011.572969.

21. Soni P, Khandelwal K, Aara N, Ghiya BC, Mehta RD, Bumb RA. Efficacy of intralesional bleomycin in palmo-plantar and periungual warts. J Cutan Aesthet Surg. 2011;4:188-91. https://doi.org/10.4103/0974-2077.91250.

22. Saitta P, Krishnamurthy K, Brown LH. Bleomycin in dermatology: a review of intralesional applications. Dermatol Surg. 2008;34:1299-313. https://doi.org/10.1111/j.1524-4725.2008.34281.x.

23. Dhar SB, Rashid MM, Islam A, Bhuiyan M. Intralesional bleomycin in the treatment of cutaneous warts: a randomized clinical trial comparing it with cryotherapy. Indian J Dermatol Venereol Leprol. 2009;75:262-7. .https://doi.org/10.4103/0378-6323.48428.

24. Aziz-Jalali MH, Ghafarpour G, Rezaei MR, Behzadi AH, Nasab MR, Nilforoushzadeh MA. Efficacy of intralesional bleomycin in the treatment of resistant warts. J Skin Stem Cell. 2014;1:1887. https://doi.org/10.17795/jssc18875.

25. Canellos GP, Duggan D, Johnson J, Niedzwiecki D. How important is bleomycin in the adriamycin + bleomycin + vinblastine + dacarbazine regimen? J Clin Oncol. 2004;22:1532-33. https://doi.org/10.1200/JC0.2004.99.010.

26. Bayer RA, Gaynor ER, Fisher RI. Bleomycin in non-Hodgkin's lymphoma. Semin Oncol. 1992;19:4652.

27. Kawai K, Akaza H. Bleomycin-induced pulmonary toxicity in chemotherapy for testicular cancer. Expert Opin Drug Saf 2003;2:587 - 96. https://doi.org/10.1517/14740338.2.6.587.

28. Pautier P, Gutierrez-Bonnaire M, Rey A, Sillet-Bach I, Chevreau C, Kerbrat P, et al. Combination of bleomycin, etoposide, and cisplatin for the treatment of advanced ovarian granulosa cell tumors. Int J Gynecol Cancer. 2008;18:446-52. https://doi.org/10.1111/j.1525-1438.2007.01049.x.

29. Tobias J, Buxton EJ, Blackledge G, Mould JJ, Monaghan J, Spooner D, et al. Neoadjuvant bleomycin, ifosfamide and cisplatin in cervical cancer. Cancer Chemother Pharmacol. 1990;26:59-62. https://doi.org/10.1007/BF00685422.

30. Silverman S Jr, Gorsky M, Lozada F. Oral leukoplakia and malignant transformation. A follow-up study of 257 patients. Cancer. 1984;53: 563-8. https://doi.org/10.1002/1097142(19840201)53:3<563::aidcncr2820530332>3.0.co;2-f.

31. Stich HF, Hornby AP, Mathew B, Sankaranarayanan R, Nair MK. Response of oral leukoplakias to the administration of vitamin A. Cancer Lett. 1988;40:93-101. https://doi.org/10.1016/03043835(88)90266-2.

32. Shah JP, Strong EW, De Cosse JJ, et al. Effects of retinoids on oral leukoplakia. Am J Surg. 1983;146:466-70. https://doi.org/10.1016/0002-9610(83)90232-5.

\section{Figures}



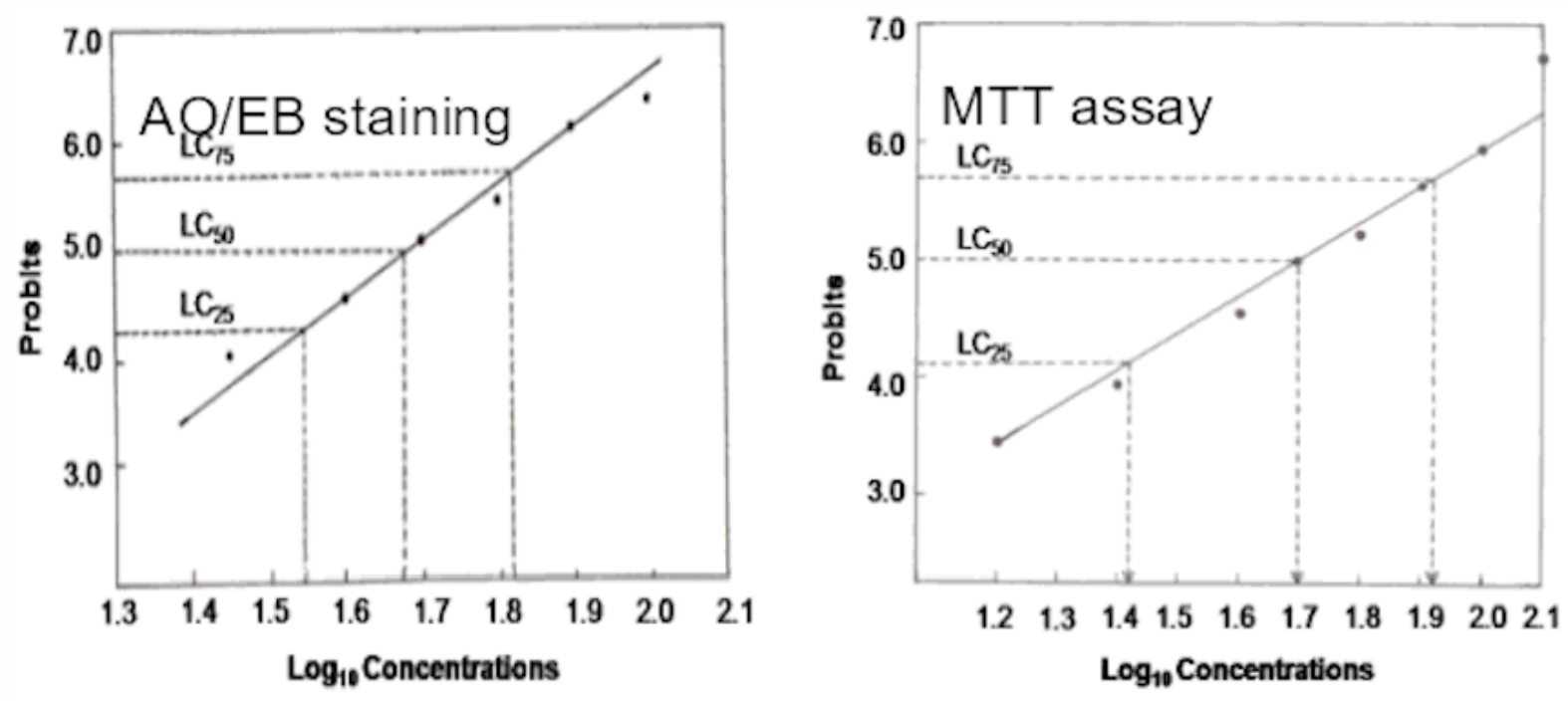

\section{Figure 1}

Probits of percentage lethality values plotted against $\log 10$ concentrations of Bleomycin in the toxicity study of leukoplakia cell line, D38; three log10 concentration values were determined taking probit points, from which, log 10 concentrations for LC25, LC50 and LC75 by AO/EB staining and MTT assay were determined.
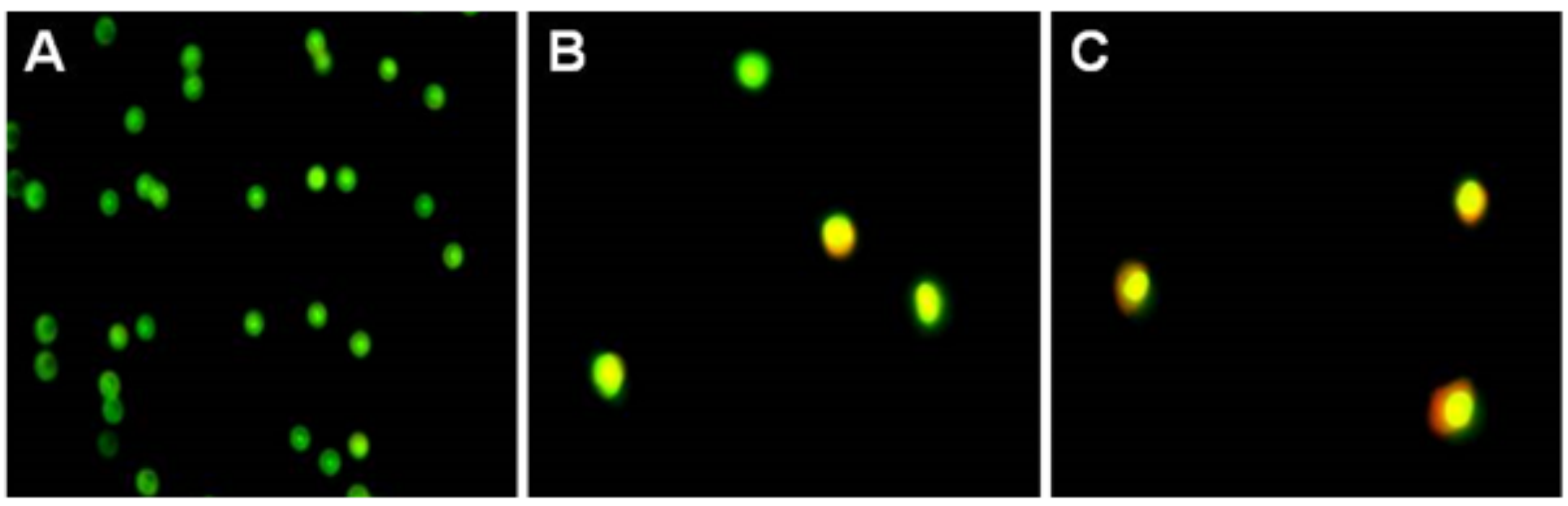

\section{Figure 2}

Acridine orange/ethidium bromide staining. (A) Control cells (B) Cells after treated with $25 \mathrm{mg} / \mathrm{L}$ Bleomycin, (C) 50 mg/L Bleomycin. 


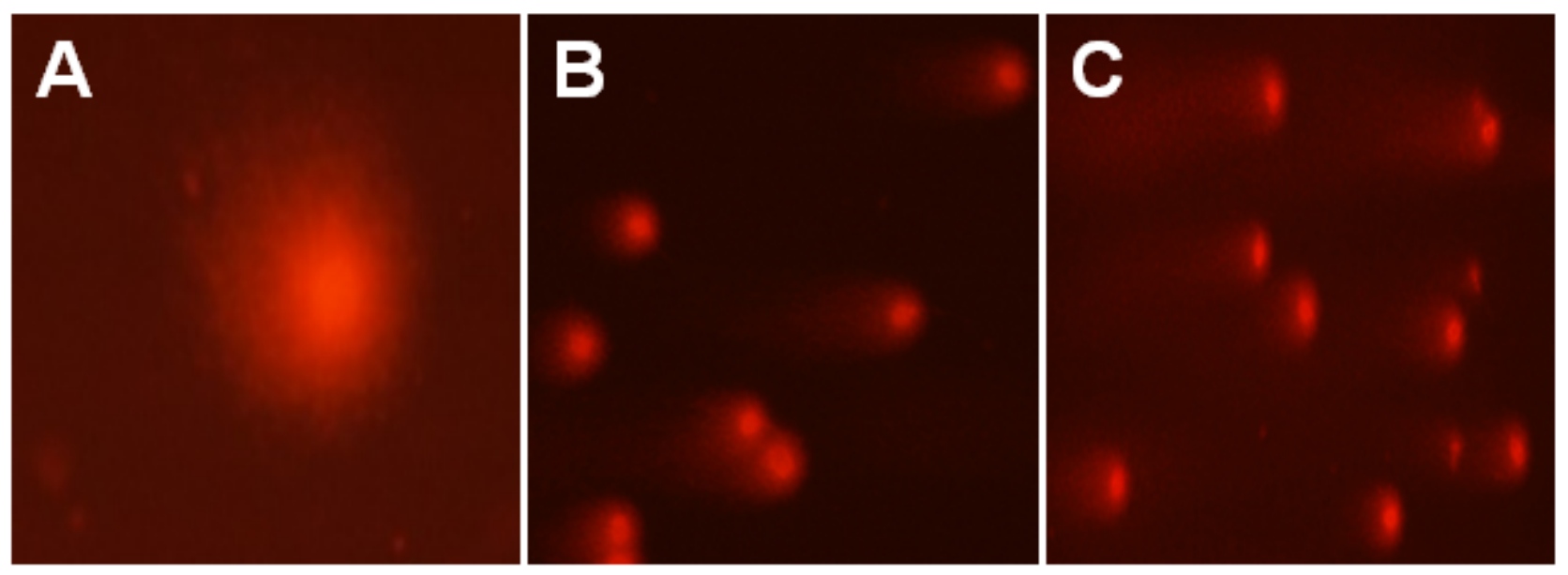

Figure 3

Comet assay. (A) Control cells, (B) Cells with comets after treatment with $100 \mu \mathrm{M} \mathrm{H} 2 \mathrm{O} 2$ as positive control, (C) Cells with comets after treatment with $42.76 \mathrm{mg} / \mathrm{L}$ Bleomycin . 